\title{
THE ROLE OF MOUING IMAGES IN THE CONFERENCE INTERPRETING CLASSROOM
}

\author{
Susi Septaviana Rakhmawati \\ Universitas Pendidikan Indonesia \\ cseptaviana@gmail.com
}

First received: 10 April 2015

Final proof received: 25 January 2016

\begin{abstract}
This paper reports on the study of the student interpreters' performance in conference interpreting classes in an Indonesian university when multimodal texts were provided as part of the teaching methods. It aims to answer how multimodal texts can influence interpreting performance among students. A case study design was used to allow an in-depth analysis of the students' interpreting performance as the phenomenon described (Yin, 2003) using triangulation of data analysis. Observation, interview, and seven transcription analysis from three students were carried out. Observation and interview result shows that the students used visual information such as lips movement, running text on video, moving images, and the speakers' gestures in their interpreting processes. Moreover, the students said that the existing method of teaching interpreting using multimodal texts is really helpful for them in developing their interpreting skills. Furthermore, transcription analysis also confirms that the student with multimodal strategies (facing the speaker, the screen/the video) performed better during interpreting process. However, a student who faces both did not seem to perform well. The indication is that he was unable to focus, being distracted and nervous. Thus, overall the student interpreters used visual information as part of multimodal communication, in addition to speech, working on the regular mode of listening and speaking during interpreting process, which suggest significant contribution of multimodal texts to better rendition in the target language.
\end{abstract}

Keywords: Simultaneous Interpreting, student interpreters, multimodality, interpreters' training.

Moving images as one of the modes in communication are then coined for multimodal texts when combined with speech and gestures. As the technology developed so rapidly, using one modality of communication is no longer everyday reality to most people. Even within a view of 'traditional', with no media, communication between people is naturally multimodal. People employ speech, facial expressions, eye gaze, and gesture, among other facilities, to support communication and cooperative activity (Piper and Hollan, 2009).

Moving images in light of use in this paper include the use of speech, gestures including lip movement and running texts. The use of moving images as part of multimodal texts is considered as a move away from the so-called traditional interpreting practice e.g. for students by providing only audio resources. Even so spoken discourse alone which counts for the main source material for interpreting is highly multimodal. People communicate not only verbally but also with the use of nonverbal features such as body language and vocal cues. Thus, it seems extremely relevant in today's research on translation and interpreting to be able to analyze source and target material that is multimodal (Remael 2001, in Hirvonen and Tiittula 2010). This research was conducted based on the initial inquiry and curiosity that there must be more than listening and speaking which covers the verbal speech mode involved in the interpretation process. Derived from the writer's years of experience as an interpreter, the underlying assumption for the present research is that an interpreter may use different modes at the same time, not only verbal mode but also nonverbal mode such as lip movement and gestures, to contribute to the meaning making in the interpreting process.

Interpreting performance has long been an issue in research and training. It is one of the interesting phenomena to explore as more demands of interpreters use in public sphere increases particularly in Indonesia. The topics investigated worldwide ranges from the process-related issues such as strategies employed by the interpreters (Pöchhacker, 2004; Galvao, 2009), comprehension, and memory (Zhong, 2003), note taking (Emilia, Septaviana and Abdullah, 2012); to the productrelated issues such as quality of interpreting performance (Septaviana, 2014), error analysis (Anazawa, Ishikawa and Kiuchi, 2012), and role of the interpreters (Pöchhacker, 2009, Davidson 2010, Jacquemet 2010, and Inghilleri, 2010).

The research topics explained above deal with professional interpreters and trainee interpreters as the subjects. According to Galvao (2009) majority of research investigating non-verbal communication has involved trainee interpreters which poses challenges to relate the findings to professional 
interpreters working in a real conference setting (Alonso Bacigalupe 1999:135, and Pöchhacker 2004:199 in Galvao 2009). However, arguably to ensure good quality of professional interpreters, it must start from good quality of interpreters' training. Some scholars (Hale, 2007; Pöchhacker, 2004; Gile, 1995) have discussed interpreters' training from the perspective of training in general and teaching and learning in specific. The discussions are centered on mostly curricula used and teaching methods. This paper explores the teaching learning situation in an interpreting class which focuses on the media - multimodal texts - the lecturer used and how it contributed to the interpreting performance of the students. Furthermore, it explains the results of careful and brief investigation on English department students in an Indonesian university taking the subject of Conference Interpreting as one of the compulsory subjects. It aims to answer whether the multimodal texts in terms of speech, moving images, gestures and lip movements help the student deliver good interpretation.

Interpreting and translation have never been singled out as to use only one mode. In the use of speech alone it involves listening and speaking as well as reading visual cues in the process of interpreting for instance. It is therefore justifiable that multimodality has become an important watchword in this field along with other fields as well. Before arriving at the definition of multimodality and multimodal texts, it is necessary to understand the concept of semiotic mode underlying the concept used. According to Kress et al medium that we use refer to the material substance which is worked on or shaped over time by culture into an organized, regular, socially specific meaning of representation, i.e. a meaning making resource or a mode (Kress and van Leeuwen 2001:15). Moreover, Kress says that

\footnotetext{
Mode is socially shaped and culturally given resource for making meaning. Image, writing, layout, music, gesture, speech, moving image, soundtrack are examples of modes used in representation and communication (in Jewitt 2011:54)
}

It is necessary to highlight that on the basis of this concept of semiotic mode, the social semiotic scholars (Kress, 1997; Kress and van Leeuwen, 1996) propose the concept of "multimodality" to account for the multimodal communication; that is, all kinds of meaning making are always employed with a multiplicity of modes of representation (in Chuang, 2006). This concept describes that language, whether in speech or writing, has always existed as just one mode in the totality of modes involved in the production of any text, spoken or written. A spoken text is not just verbal but also visual, combining with 'non-verbal' modes of communication such as facial expression, gesture, posture and other forms of self-presentation (Chuang, 2006). Consequently, multimodality is about the combined use of several semiotic modes so as to design a semiotic product or event (Kress and Van Leeuwen, 2001). Modes work independently and collectively all at once in multimodal communication. It signifies that, "modes produce meaning in themselves and through their intersection or interaction with each other" (Kress et al. 2001: 14). Stöckl (2004: 9) in Hirvonen and Tittula (2010) brings the concept further by saying that

\begin{abstract}
Multimodal refers to communicative artifacts and processes which combine various sign systems (modes) and whose production and reception calls upon the communicators to semantically and formally interrelate all sign repertoires present.
\end{abstract}

Thus, multimodality refers to relations established between different sign systems (or modes, or semiotic resources), and multimodal communication can be described as congruent meaning making based on the interactive presence of different meaning making systems (ibid.)

As mentioned earlier, moving images is one element considered to make up a whole multimodal text in addition to speech and gestures. No text is, strictly speaking, monomodal (Gambier, 2006). This paper uses moving images which include the use of speech, gestures including lip movement and running texts. Multimodal text here is the use of texts as objects which use more than one mode of meaning-making (Kress, Jewitt, Ogborn and Tsatsarelis, 2001). Furthermore, Kress and van Leeuwen (2001) describe of the multimodality of text:

"We want to insist from the beginning that the
semiotic instances in which we are interested - the
texts - include the everyday practices of 'ordinary'
humans as much as the articulations of discourses in
more conventionally text-like objects such as
magazines, TV programs, and so on. We will refer
to these [as] 'practically lived texts'. (in Jewitt, 2011)

Taking the keyword of practically lived texts from the definition above, multimodal text used in the conference interpreting classroom as the site of this study is in terms of downloaded VOA news video which comprises moving image, running text and speech as well as gestures - e.g. lip movement. Gestures particularly lip movement is considered as visual input contributing to the meaning making in the comprehension of interpreting process.

Before moving on to see how multimodal texts play a role in simultaneous interpreting, it is necessary to lay the foundation of the concept of interpreting. Interpreting is defined as a form of 
translation in which its first and final rendition is produced only one time (Pöchhacker, 2004). Conference interpreting is the setting where interpreting services is needed in which simultaneous interpretation is the primary use of interpreting mode although sometimes consecutive interpretation is also necessary. Simultaneous interpreting (SI) is a specific form of speech and can be defined as "spokenlanguage interpreting with the use of simultaneous interpreting equipment in a sound-proof booth" (Pöchhacker 2004: 19). Simultaneous interpreting also means that the interpreter listens to the source language speaker and interprets at the same time without any pauses from the SL speaker. It requires an excellent skill of multitasking between listening and interpreting simultaneously. By doing so, interpreting delivery must deliver good rendition. It is inevitable that an interpreter has to keep up with accuracy and fidelity as both of the two are the most widely acknowledged demand concerning an interpretation that should be both faithful and accurate to the original (Pöchhacker, 2004). The postulate of "faithfulness as measured by the extent to which people really comprehend the meaning" (Nida and Taber 1969: 173) is a crucial translational norm underlying the interpreter's production" (Ibid.).

Fidelity also means that there must be no over and under translation (Tateyama, 2008) in which no significant omission occur (Harris, 1990 in Pöchhacker, 2004). The extent to which accuracy is required should be at message level (Gile, 1995), and at a deeper semantic level (Mackintosh, 1983 in Pöchhacker, 2004). Furthermore, Gile calls for fidelity to the message and style of the original, with ultimate importance precede the "informational content" rather than the linguistic "package" of the text (see Gile 1995:26). Therefore, this paper favors the definition of fidelity and accuracy as coined by Gile as it is relevant since accuracy must be at the message level where no significant omission occurs. Omission is inevitable as it is one of the features in SI (Hale 2007) as long as it is non-content aspect.

Translation and interpreting often interplay with the semiotics of the human body (PérezGonzález, 2014). This term designates the use of para-verbal signs - including but not limited to voice qualities, cadence, inflection, or rate of speech - and non-verbal signifiers - such as gestures or movements (Poyatos 1997, in Pérez-González, 2014). Simultaneous Interpreting has been recognized as a multimodal communication phenomenon. Bühler was probably one of the first scholars in SI to describe conference interpreting as a multichannel communication phenomenon (in Galvao, 2009). However, according to Galvao (2009), studies on non-verbal communication and SI have been focusing on demonstrating the relevance or irrelevance of what has been variously termed the speaker's 'body language', 'visual input', etc., for good performance in the booth (2009). She further listed a number of empirical and non-empirical studies (Bühler 1985; Poyatos 1997; Rennert 2008; Viaggio 1997; and Weale 1997), that have argued that interpreters must be able to see the speakers, ideally, also the audience in order "to convey the totality of the original message, since the verbal input [is] supplemented by non-verbal elements essential for the understanding of the message" (Sineiro de Saa 2003: 40 in Galvao, 2009).

Other studies scrutinizing the concept multimodality in interpreting field have actually been underrepresented in terms of number. Many researches focus more on audio visual translation and/or film translation when analyzing them with a multimodal approach. As has been quoted earlier, Galvao (2009) investigates the speech-gesture ensemble in SI and compared a speaker's verbal and non-verbal modalities to his/her simultaneous interpreter's verbal and non-verbal modalities. Another relevant study is by Bührig (2004) who studies multimodality in medical interpreting. It explores untrained interpreting in doctor-patient communication in German hospitals. A certain type of hospital interaction with a patient i.e. the briefing for informed consent is the focus. It particularly describes the doctor's and the non-trained interpreter's use of diagram in the SL (German) and TL (Portuguese). The analysis shows how different diagram used in the consultation sessions influence respective speech action patterns and suggests what the implications are for transferring knowledge to the patient.

When Bührig studies is on medical interpreting, Pasquandrea (2012) focuses on interpreting in healthcare settings, with regards to a corpus of medical encounters involving Italian doctors, Chinese patients and an Italian interpreter. The study is centered on conversation analysis and multimodal communication. Furthermore, the aim of this study is to investigate how the interactants coconstruct dyadic sequences through verbal and nonverbal means. The final stage of the sequences is analyzed, i.e. the translation from Chinese to Italian, to point out that closing the dyadic sequence and starting the translation is the outcome of an intricate discussion. This involves all the participants who use semiotic resources to carry out their communicative actions.

Previous studies elaborated above focus on the investigation of practicing interpreters whether they are trained or untrained interpreters. There has not been any research, to the best of the writer's knowledge on the use of multimodal means moving images - in teaching interpreting skills. Thus, this study pays attention to how moving images influence the student learning and developing their interpreting skills in EFL context. 


\section{METHOD}

Case study design was applied as the guiding principle of qualitative approach in this study. A case study is an exploration of a "bounded system" or a case (or multiple cases) over time through detailed, in-depth data collection involving multiple sources of information rich in context (Creswell, 1998). Thus, to use a case study design is considered appropriate since the study investigated the case of using moving images in students' interpreting practice through an in-depth analysis which relies on observation, transcription and interview as multiple sources of evidence with triangulation of data to verify the reliability of the findings (Yin, 2003).

A conference interpreting class was observed as the site of the subjects - about 30 English department students. The students were at the beginning of their third year learning English as their major, in the context of EFL. During interpreting practices, the students can choose to face the audience with the screen of moving images in their background or to face the screen with audience in their back. Some students chose to interpret twice of the same video; first by facing the audience and then second time by facing the screen. During mid-term test interpreting all students must interpret from their "booth" in the laboratory using headset. However, due to space limitations this paper will focus only on three students representing the student who faced the audience only, the student who faced both the audience and the screen, and the student who faced the screen only during their interpreting practices. The limitation of this data on subjects was that the study did not investigate the correlation of their interpreting performance with their grades on interpreting subjects and their GPAs overall in English language. Moreover, due to the class is still on-going, the data collected covered only the first half of the semester which comprised seven practice sessions ( 7 weeks). Thus, the transcriptions analyzed were that of the first-time interpreting practice and mid-term test interpreting practice. For the first-time interpreting practice, the speaker was in the form of video (multimodal text) and it was VOA news. The video consisted of moving images, gestures i.e. lip movements of the speakers was played once.

As part of the teaching phases, the first phase was that the students were all watching all parts of the texts for comprehension and taking notes if necessary for difficult terms. Subsequently, the students were asked to repeat, explain and summarize using English as the source language. The second phase is that the students were asked to simultaneous sight translate the running texts while listening to the speech into Indonesian. For the third phase, each student voluntarily came forward to interpret certain segment of the texts. Some students faced the video or the speaker when interpreting and the running texts were hidden. Some other faced the audience and the rest faced both the audience and the video. As for the mid-term interpreting practice, the students interpreted simultaneously in the laboratory using equipment such as headset, lecturer-operated audio transfer which was only played once and it was automatically recorded. The data collected for this paper therefore seven different short transcriptions of simultaneous interpretation from three students. The recordings were done using audio recorder and then they were transcribed. Coding system was applied to simplify the description and maintain the research ethics for the students' name. The coding applies for the student who faces both the screen and the audience is 'FB', faces screen is 'FS' and faces audience is 'FA'.

Open interview (Yin, 2003) in which it was brief and unstructured was administered to ask the students about their impression and the difference between facing the video, facing the audience and both. This type of open, unstructured interview has an advantage of the resulting richness of insight it can generate (Richard in Heigham and Croker, 2009). Participatory observation was also carried out to see and verify the data collected through transcription and interview.

Analysis to the transcriptions was done to see if the students accurately interpret the news. They were then compared between three groups of different students transcriptions who faced the audience, the video and both the audience and the video. Following the result of the transcriptions, the data was triangulated with interview and observation results. Triangulation was a necessary stage of data analysis as Hammersley and Atkinson (1983) define it as 'the comparison of data relating to the same phenomenon but deriving from different phases of the fieldwork, different points in the temporal cycles occurring in the setting, or... the accounts of different participants...differentially located in the setting' (in Heigham and Croker, 2009).

\section{FINDINGS AND DISCUSSION}

This section explains the findings based on the case in terms of how the multimodal texts influence students in their interpreting performance. This is illustrated in each section of data collection method and analysis using the criteria of message fidelity and accuracy (Harris 1990, Gile 1995, and Tateyama, 2008).

The finding from the transcription analysis shows that students who utilized moving images as a visual input to help them make meaning and comprehend the message of the source language outperform the students who 'only' listen to the audio of the SL speaker. This is evident in the following cases. 


\section{The student who faced the screen looking at multimodal text (moving image, gesture and speech)}

This case of student who faced the screen when interpreting showed consistent result from the analysis of the finding yielded from the observation, interview and transcription analysis. During the practice, it was observed that this student seemed to believe in herself and yet showed her calm nature. She looked focused and determined. Her facial expression and body positioning when interpreting showed that she was not distracted by the screen. Moreover, it was confirmed by her response when asked of her impression after the practice. She said "mouth movements help me to understand the words uttered by the speaker especially the names of people which are the difficult part to catch in the interpreting session this time."

The transcription analysis shows that this student has managed to interpret well the message simultaneously. Main ideas and all sentences were rendered to the target language accurately and completely. This is in line with what has been stated previously that to render accurately an interpreter must convey its message and style. Only three insignificant omissions took place, which means that these did not change the whole message. In addition, mispronouncing two names was considered as not a major violation to the accuracy.

\subsection{First interpreting practice}

SL : Another favorite is "Truly Madly Deeply" by Savage Garden. Another person, Asi Tambunan suggested the song "God Only Knows" by Orianthi. Gyongyi Jako Wrote that ABBA's songs from Sweden are perfect for class work. Other good songs for learning English are songs by the Beatles and John Lennon, as well as Louis Amstrong's "Wonderful World". Paul Cifuentes says Bob Marley's songs are amazing for teaching. Another teacher, Joseph Deka says songs by Johnny Cash have always worded in his classroom. He says his students can hear the words, plus the songs often have stories. He also likes "We Will Rock You" by Queen and "Beautiful Girls" by Sean Kingston. He says young children love "C Is for Cookie" but Cookie Monster from the TV show "Sesame Street".

FS: Truly Madly Deeply oleh Savage Garden. Orang lainnya Asi Tambunan menyarankan lagu "God Only knows" oleh Orianthi. Yonmi yoko menuliskan bahwa ABBA songs dari Sweden sempurna untuk tugas di kelas. Lagulagu baik lain lagu untuk mempelajari bahasa Inggris.... Dan John Lennon juga Louis Amstrong Wonderful World. Paul Flances mengatakan Bob Marley lagu-lagu Bob Marley luar biasa luar biasa untuk diajarkan.
Guru lainnya Joseph Deka mengatakan lagulagu seperti Johnny Cash berhasil diajarkan di kelasnya. Ia mengatakan siswa-siswanya bisa mendengarkan kata-katanya juga lagu-lagu We Will Rock You oleh Queen dan Beautiful Girls oleh Sean Kingston. Dia mengatakan anak-anak menyukai $\mathrm{C}$ is for Cookie oleh Cookie Monster dari program TV Sesame Street.

It can be seen from the excerpt above that this student conveyed the message accurately. Moreover, the majority of names of people and songs were also transferred completely. This student 'only' omitted the three phrases "another favorite", "by the Beatles" and "plus the songs often have stories". Though ideally these omitted phrases must be conveyed particularly "by the Beatles", it does not change the whole message in which the target text still retains its completeness of message and faithful rendition of the style of SL.

In the excerpt below, the student interpreted in the lab simultaneously with equipment. It was like a "booth". It is necessary to provide near real-life context so that the student could get the feeling what it is like to be in such situation of interpreting using equipment. It can be seen in the following that the student maintained her good interpreting performance, and made a progress this time by omitting only one word and mispronouncing two names.

\subsection{Mid-term test interpreting}

SL: I started learning English with "Lemon Tree" by Fool's Garden. Another favorite is "Truly Madly Deeply" by Savage Garden. Another person, Asi Tambunan suggested the song "God Only Knows" by Orianthi. Gyongyi Jako Wrote that ABBA's songs from Sweden are perfect for class work. Other good songs for learning English are songs by the Beatles and John Lennon, as well as Louis Amstrong's "Wonderful World". Paul Cifuentes says Bob Marley's songs are amazing for teaching. Another teacher, Joseph Deka says songs by Johnny Cash have always worded in his classroom. He says his students can hear the words, plus the songs often have stories. He also likes "We Will Rock You" by Queen and "Beautiful Girls" by Sean Kingston. He says young children love "C Is for Cookie" bu Cookie Monster from the TV show "Sesame Street".

FS Int : Aku mulai belajar bahasa Inggris dengan London Tree oleh Fool's Garden. Favorit lainnya yaitu "Truly, Madly Deeply" oleh Savage Garden. Orang lainnya, Ashley Tambunan menyarankan lagu God Only knows oleh Orianthi. Yami Yako menuliskan bahwa lagu lagu ABBA dari Swedia 
sempurna untuk pengajaran di kelas. Lagu lagu baik lainnya untuk belajar bahasa Inggris adalah lagu lagu dari The Beatles dan John Lennon, juga Louis Armstrong "Wonderful World". Holsi Quintes mengatakan bahwa lagu lagu Bob Marley luar biasa untuk diajarkan. Guru guru lainnya, Joseph Deka, mengatakan lagu lagu seperti Johny Cash selalu berhasil di kelasnya. Dia mengatakan siswa siswanya bisa mendengarkan suara suara dan lagu lagu biasanya memiliki, dia juga, "We Will Rock You" oleh Queen dan "Beautiful Girls" oleh Sean Kingston. Dia mengatakan anak anak kecil suka $\mathrm{C}$ is for Cookie oleh Cookie Monster dari TV program sesame street.

FS student showed significant progress from the first interpreting practice to the mid-term test interpreting. She managed to convey the omitted words which were done previously in this interpreting session. This showed that she had good skills in interpreting. Moreover, she maintained the already conveyed words and sentences in an accurate and complete way. Even though there were mispronunciations of the word "Lemon" into "London" and "Gyongyi Jako" into "Yami Yako", those words almost sound similar and in interpreting practice having difficulty in recognizing unfamiliar names was a common feature. In addition, only insignificant omission occurred that was the word "stories." This was justifiable since one of the inevitable features of Simultaneous Interpreting was insignificant omission. The student did this may be because she didn't have time to do it or missed it because the next words were coming. Moreover, this kind of strategy is actually important as during the class, the students are often reminded to let go of the terms that they miss and move on to the immediate words that they hear at the moment.

\section{The student was interpreting by facing both the screen and the audience}

This is an interesting case of a student who faced both the screen and the audience. During the class practice based on observation result, the student showed that he was confident with himself by voluntarily coming forward to practice twice. However, it was observed that he seemed to be distracted when facing the screen. He also seemed disoriented during mid-term test interpreting. It was clearly portrayed when the audio started, he raised his hand saying he was not ready but the audio has started anyway and all other students have started interpreting.

Consequently, as evident in his transcription of interpreting performance, he made errors and omitted a considerable number of words. He seemed to stand still in his progress of interpreting performance the second and the third time around.
He was even better in the first instance when facing the audience. However, in the interview result he said that it helped him a lot in the interpreting process when looking at the screen. When probed further, he admitted that he had difficulty to concentrate second time he interpreted the video so he had difficulty in catching names particularly. He said

"I personally realized that being familiar with some English terms and English names were important for the interpreter to catch the names and terms and also pronounce them correctly. Another important thing is by looking the speaker's mouth movements. By doing that, it can help me focus on what I watch and what I hear. It is a bit different when I do not see the speaker. Obviously, I feel that mouth movements and gestures help me interpret the speaker especially when the speaker says a person's name or difficult terms. The shape of the lips helps me identify the word uttered by the speaker when i don't hear clearly."

In the following, the transcription analysis shows that the student made consistent errors and omission as well as did not show any progress in terms of the number of errors and omissions occurring in these three transcriptions.

\subsection{The student was interpreting while facing the audience}

SL : Another person, Asi Tambunan suggested the song "God Only Knows" by Orianthi. Gyongyi Jako Wrote that ABBA's songs from Sweden are perfect for class work. Other good songs for learning English are songs by the Beatles and John Lennon, as well as Louis Amstrong's "Wonderful World". $\underline{\text { Paul }}$ Cifuentes says Bob Marley's songs are amazing for teaching. Another teacher, Joseph Deka says songs by Johnny Cash have always worked in his classroom. He says his students can hear the words, plus the songs often have stories. He also likes "We Will Rock You" by Queen and "Beautiful Girls" by Sean Kingston. He says young children love "C Is for Cookie" bu Cookie Monster from the TV show "Sesame Street".

FB : Orang lainnya yaitu Asri Tambunan menyarankan lagu-lagu God Only Knows, Orianthi, ....Yemiyako menulis bahwa.....dari Swedia adalah sangat sempurna untuk pekerjaan kelas. Lagu bagus lainnya untuk belajar bahasa Inggris yaitu lagu dari The Beattles dan John Lenon juga lagu Louise Amstrong, Wonderful World. .... Mengatakan bahwa lagu Bob Marley juga sangat luar biasa untuk diajarkan. Guru lain Joseph Deka mengatakan bahwa lagu dari Jonny Cash, sangat bekerja di kelasnya. Dia mengatakan siswanya dapat mendengar lagunya dengan sangat jelas dan bisa menangkap ceritanya, 


\section{We Will Rock You dari Queen dan Beautiful Girl oleh Sean Kingston}

As it is shown above, at the first instance of interpreting he conveyed the message accurately and completely with only one mistake of pronouncing a name and three omissions. It suggests that the student did quite well in transferring the message. The overall message can still be understood.

However, it is interesting to find out that he regressed when interpreting in the lab and when facing the screen. From the interview, it was clear that he pointed out that listening and conveying names was important. This was when he was a bit struggling. It is believed that this kind of error is natural since the student is not professional interpreter and he is still learning English as a foreign language. So this unique case is not to be generalized in which it applies to all students who face both ways and it certainly cannot be held true for professional interpreter. In the following, the transcription shows the errors in more detail.

\subsection{The student was interpreting by facing the screen}

SL : Another person, Asi Tambunan suggested the song "God Only Knows" by Orianthi. Gyongyi Jako Wrote that ABBA's songs from Sweden are perfect for class work. other good songs for learning English are songs by the Beatles and John Lennon, as well as Louis Amstrong's "Wonderful World". Paul Cifuentes says Bob Marley's songs are amazing for teaching. Another teacher, Joseph Deka says songs by Johnny Cash have always worded in his classroom. He says his students can hear the words, plus the songs often have stories. He also likes "We Will Rock You" by Queen and "Beautiful Girls" by Sean Kingston.

FB : yang lainnya yaitu Tambunan menyarankan lagu Gods Only Knows oleh Yanti, Hyoko dari Swedia (jeda) lagu bagus yang lainnya yaitu lagu The Beatles dan John Lennon juga Louis, juga Louis Armstrong yaitu Wonderful World. Mengatakan bahwa sangat luar biasa untuk diajarkan guru lainnya yaitu Joseph Deka mengatakan bahwa lagu mem- memililagu itu selalu bekerja dalam kelas (jeda) juga (jeda) dia juga menyukai I will Rock You oleh Queen dan Beautiful girl oleh Shawn Kingston (jeda).

When facing the screen, the student covered the majority of the message even though a number of words have been omitted. As evident in the excerpt above, the student omitted some words that were interpreted correctly in previous practice. It is a unique phenomenon but not uncommon one. Students are still learning English and they have just started learning interpreting skills. Interpreting particularly SI requires multitasking of senses because they must work together to comprehend the source language message and construct the meaning as well as render them into the target language. Thus, one of the possible reasons aside from being nervous is that the student has not acquired automatisation and/or orchestration of various modalities. The more senses the students use the less they are able to coordinate them. Observation also found that he exhibited signs of distracted and nervousness.

\subsection{Mid-term test interpreting}

SL : Another person, Asi Tambunan suggested the song "God Only Knows" by Orianthi. Gyongyi Jako Wrote that ABBA's songs from Sweden are perfect for class work. Other good songs for learning English are songs by the Beatles and John Lennon, as well as Louis Amstrong's "Wonderful World". Paul Cifuentes says Bob Marley's songs are amazing for teaching. Another teacher, Joseph Deka says songs by Johnny Cash have always worded in his classroom. He says his students can hear the words, plus the songs often have stories. He also likes "We Will Rock You" by Queen and "Beautiful Girls" by Sean Kingston. He says young children love "C Is for Cookie" by Cookie Monster from the TV show "Sesame Street".

FB :Orang lainnya yaitu Asi Tambunan me... mengajarkan lagu God Only Know oleh Rianti. Rahmi Yako dari Sweden sangat luar ee sangat ee sangat untuk tugas kelas. Lagu mengajarkan bahasa Inggris dan John Lenon juga Louis Armstrong Wonderful World Mengatakan bahwa semua lagu eee untuk belajar untuk mengajarkan guru guru lainnya mengatakan bahwa semua lagu sangat bekerja di kelasnya. Dia mengatakan bahwa eee siswanya dapat mendengarkan karena dan lagu memiliki sejarah dia juga sangat menyukai We Will Rock You oleh Queen dan Beautiful Girl oleh Sean Kingston

While in the above transcription, it was evident that he omitted the words that were conveyed previously and maintained the errors. It is also observed that when starting the test he raised his hand to sign he was not ready even though the lecturer has asked several times if the students were ready to start the test after they were given time to prepare and to check the equipment.

\section{The student was interpreting by facing the audience}

The third case is the student who faces the audience. As a reminder the student voluntarily chose whether he wanted to face the audience, the screen, or both. This student chose to face the audience even when he was asked if he would like to face the screen. During interpreting process, he seemed to smoothly 
convey the meaning into the target language. He faced the audience but he closed his eyes when interpreting. When asked about his impression of the practice, he said

\begin{abstract}
"For me, closing my eyes and focusing on the speaker's voice is the easiest way to do interpreting. When you close your eyes, you can focus on the words that you received and stored in your minds before you utter it to the audience. The other key is not being distracted by your own voice when you uttered the words. When you cannot do it in a phrase, just do with another phrase. When you close or inactivated one of your senses the other senses will be more sensitive."
\end{abstract}

Following is the transcription of the interpreting in which two practices were performed. During these practices, the student must simultaneously interpret while listening to the video which was played in his background while he was sitting facing the audience.

\subsection{First-time interpreting practice}

SL : Another person, Asi Tambunan suggested the song "God Only Knows" by Orianthi. Gyongyi Jako Wrote that ABBA's songs from Sweden are perfect for class work. other good songs for learning English are songs by the Beatles and John Lennon, as well as Louis Amstrong's "Wonderful World". Paul Cifuentes says Bob Marley's songs are amazing for teaching. Another teacher, Joseph Deka says songs by Johnny Cash have always worked in his classroom. He says his students can hear the words, plus the songs often have stories. He also likes "We Will Rock You" by Queen and "Beautiful Girls" by Sean Kingston.

FA : Orang lainnya adalah Asi Tambunan menyarankan lagu God Only Knows dari Orianti. Jacob meulis bahwa ABBA song dari Swedia sangatlah sempurna untuk diajarkan di kelas. Lagu yang bagus lainnya untuk diajarkan bahasa Inggris adalah lagu yang dibikin dari The Beatles dan John Lennon. Seperti yang dikatakan Louis Amstrong yaitu lagu Wonderful World. .... lagu-lagu Bob Marley sangat bagus untuk diajarkan. Guru lainnya Joseph Deka mengatakan lagu Johny Case selalu diajarkan di kelasnya. Dia mengatakan pada murid-muridnya bahwa murid-muridnya dapat mendengar katakatanya dan lagu tersebut memiliki cerita yang bagus. Dia juga mengatakan bahwa We Will Rock You dari Queen dan Beautiful Girl dari Sean sangatlah bagus untuk diajarkan.

The transcription above showed that the student performed quite well during interpreting process. The message was conveyed clearly and he made only two omission and two mispronouncing words. Even though from the observation the student seemed to speak in a natural flow without hesitation, it turned out that there were several additions like "lagu tersebut memiliki cerita yang bagus" (the song has good stories), "seperti yang dikatakan Louis Amstrong" (As said by Louis Amstrong), "pada murid-muridnya (to his students) in between the words "he says that his students...", "sangatlah bagus untuk diajarkan" (is very good to be taught) after the words 'Beautiful Girls by Sean Kingston' and some deviation of message such as 'learning' for 'being taught' (diajarkan), 'have always worked' for 'have always been taught' (Selalu diajarkan), and 'he likes' becomes 'he says'(dia mengatakan). This clearly indicates a serious issue of accuracy since there are some additions which deviate from the original meaning and there are mistranslations. These mistranslations even have different conceptual meaning such as 'learning' becomes 'being taught' which can have some implication on the hearers. As stated previously, Tateyama (2008) suggests that the meaning of accuracy is that there should be no over and/or under translation.

\subsection{Mid-term test interpreting}

SL : Another person, Asi Tambunan suggested the song "God Only Knows" by Orianthi. Gyongyi Jako Wrote that ABBA's songs from Sweden are perfect for class work. Other good songs for learning English are songs by the Beatles and John Lennon, as well as Louis Amstrong's "Wonderful World". Paul Cifuentes says Bob Marley's songs are amazing for teaching. Another teacher, Joseph Deka says songs by Johnny Cash have always worked in his classroom. He says his students can hear the words, plus the songs often have stories. He also likes "We Will Rock You" by Queen and "Beautiful Girls" by Sean Kingston. He says young children love "C Is for Cookie" by Cookie Monster from the TV show "Sesame Street".

FA : Orang lain, adalah Asi Tambunan, mennyarankan lagu God Only Knows dari Orianti. Yako menulis lagu ABBA sangat baik untuk diajarkan di kelas. Lagu lain yang bagus untuk belajar bahasa inggris adalah lagu dari The Beatles dan John Lennon. Seperti yang dikatakan oleh Louis Armstrong Wonderful World. Lagu Bob Marley juga sangat bagus untuk diajarkan. Guru lainnya, Joseph Dekka, mengatakan lagu-lagu dari Johnny Cash sangat bagus untuk di kelasnya. Dia bilang, murid-muridnya mengerti lagunya. Dan lagu itu mengajarkan banyak ...... Dia juga suka We Will Rock You dari QUEEN dan Beautiful Girl dari Kingston. Dia bilang, bahwa anak- 
anak kecil suka dari Cookie Monster acara TV sesame street.

Unlike the first interpreting practice, FA student here in the above transcription shows a good progress even though a few numbers of errors are still evident. He omitted 'Paul Cifuentes', 'often have stories', 'Sean' and ' $\mathrm{C}$ is for'. In addition, he still mispronounced a name and three additions which constitutes relative deviation of message such as 'class work' into 'being taught' (diajarkan), 'hear' into 'understand' (mengerti), and 'plus the song often have stories' into 'and the song teaches a lot...'(dan lagu itu mengajarkan banyak).

\section{CONCLUSION}

The case analyzed suggests that the students utilized visual information during interpreting practice and even before interpreting at the preparation stage. After being asked to interpret certain segment of the speech, looking at the moving images during interpreting and the running texts before interpreting particularly by seeing the speaker's lip movement the students said that it helped them catch the words and comprehend better. This was especially true for the students who practiced by facing the screen. Their impressions toward the practice were corroborated by the evidence from observation and transcription analysis. Overall in general the students who faced the screen and both the screen and the audience outperformed the students who only faced the audience. Though some omissions occurred they were not content features and no deviation of messages.

However there is a limitation to this result. The better interpreting performance at second time around may also be caused by familiarity of the texts. In addition, some errors may be the result of the factors which are not explored in this study such as the students' English proficiency. Moreover, the data collected should have been gathered until the end of the semester in which it may give a more complete picture of the students interpreting ability because it means that they must have gone through considerable number of practice sessions throughout the semester.

Finally, the result represents the case which cannot be generalized for all students learning interpretation especially in EFL context because variety of factors can contribute to their performance. One of the factors, but not limited to, is their English acquisition let alone their interpreting skills. Obviously these cases cannot be generalized to indicate the performance of professional interpreters. However, it is expected that the present study could shed light into the interpreting field and bring about a fresh perspective on how interpreting skills can be leveraged by the use of multimodal texts.

\section{REFERENCES}

Alonso Bacigalupe, Luis. 1999. "Visual Contact in Simultaneous Interpreting: Results of an Experimental Study". In Anovar/Anosar. Estudios de Traducción e Interpretación, A. Álvarez and A. Fernández (eds.). Vol. 1. Vigo: Servicio de Publicacións da Universidade de Vigo. 123-138.

Anazawa, R, Ishikawa, H, Kiuchi, T. (2012). The accuracy of medical interpretations: A pilot study of errors in Japanese-English interpreters during a simulated medical scenario.

Translation \& interpreting Vol 4, No 1. Retrieved on November, 2012 from http://trans-int.org.

Bührig, K. (2004). On the Multimuldality of Interpreting in Medical Briefing for Informed Consent. In Ventola, E., Charles, C., and Kaltenbarcher, M. (Eds). Perspective on multimodality. Amsterdam: John Benjamins B.V.

Bühler, H. (1985). "Conference Interpreting: A Multichannel Communication Phenomenon". Meta 30(1), pp. 49-54.

Chuang, Y. (2006). Studying Subtitle Translation from a Multi-modal Approach. Babel 52 (4), pp. 372-383.

Creswell, J. W. (1998). Qualitative Inquiry and Research Design: Choosing Among Five Traditions. London, UK: Sage Publications.

Davidson, B. (2010). The interpreter as Institutional Gatekeeper: the Social-linguistic Role of Interpreters in Spanish-English Medical Discourse. In Baker, M. (Eds), Critical Readings in Translation Studies (pp. 213-244). New York, NY: Routledge.

Emilia, E., Septaviana, S, and Abdullah. H. (2011). A Fresh Look on Students' Note Taking in Consecutive Interpreting: A Case in Indonesia. Lintas Bahasa 15 (1) (p.1-22)

Galvao, E.Z. (2009). Speech and Gesture in the Booth - A Descriptive Approach to Multimodality in Simultaneous Interpreting. Retrieved on April 24, 2014 from www.arts.kuleuven.be/cetra/papers/files/galvao .pdf

Gambier, Y. (2006). Multimodality and Audiovisual Translation. MuTra 2006 - Audiovisual Translation Scenarios: Conference Proceedings retrieved on November 9, 2014 from http://www.translationconcepts.org/pdf/2006_ Gambier_Yves.pdf.

Gile, D. (1995). Basic Concepts and Models for Interpreter and Translator Training. Amsterdam: John Benjamin.

Hale, S. (2007). Community Interpreting. New York: Palgrave Macmillan.

Harris, B. (1990). Norms in interpretation. Target, 2(1), pp. 115-119. 
Heigham, J., and Croker, R. A. (Eds.). (2009). Qualitative research in applied linguistics: A practical introduction. Palgrave Macmillan.

Hirvonen, M and Tiittula, L (2010). A method for analysing multimodal research material: audio description in focus. Electronic proceedings of the KäTu symposium on translation \& interpreting studies 4

Inghilleri, M. (2010). National Sovereignty versus Universal Rights: Interpreting Justice in a Global Context. In Baker, M. (Eds), Critical Readings in Translation Studies (pp. 152-173). New York, NY: Routledge.

Jacquemet, M. (2010). The Registration Interview: Restricting Refugees' Narrative Performance. In Baker, M. (Eds), Critical Readings in Translation Studies (pp. 213-244). New York, NY: Routledge.

Jewitt, C (2011). The Routledge Handbook of Multimodality. London and New York: Routledge.

Kress, G. R., and Van Leeuwen, T. (1996). Reading images: The grammar of visual design. Psychology Press.

Kress, G. (1997). Multimodal texts and critical discourse analysis. PEDRo, E.

Kress, G., Jewitt, C., Ogbom, J., and Tsatsarelis, C. (2001) Multimodal Teaching and Learning: The Rhetorics of the Science Classroom. London/New York: Continuum. xv+188 pp.

Kress, G., and van Leeuwen, T. (2001). Multimodal Discourse: The Modes and Media of Contemporary Communication. London: Arnold.

Kress, G. (2011). Mode. In Jewitt, C. (Eds.) The Routledge Handbook of Multimodality. London and New York: Routledge.

Nida, E. A. and Taber, C. R. (1969). The theory and practice of translation. Leiden: E.J.

Piper and Hollan. (2009). Analyzing Multimodal Communication around a Shared Tabletop Display. In I. Wagner, H. Tellioglu, E. Balka, C. Simone, and L. Ciolfi (eds.). ECSCW'09: Proceedings of the 11 $1^{\text {th }}$ European Conference on Computer Supported Cooperative Work, Vienna, Austria.

Pasquandrea, S. (2012). Co-constructing Dyadic Sequences in Healthcare Interpreting: A Multimodal Account. New Voices in Translation Studies 8, pp. 132-57. Available at http://www.iatis.org/images/stories/publicati ons/new-voices/Issue8-2012/IPCITI/articlepasquandrea-2012.pdfPoyatos, F. (1997).

"The reality of multichannel communication". In Nonverbal Communication and Translation (pp. 249282). F. Poyatos (ed.). Amsterdam and Philadelphia: John Benjamins.

Pöchhacker, F. (2004). Introducing Interpreting Studies. London and New York: Routledge.

Pöchhacker, F. (2009). Conference Interpreting: Surveying the Profession. Translation \& interpreting Studies 4(2), pp. 172-186. doi 10.1075/tis.4.2.02poc

Richard, K. (2009). Interviews. In Heigham, J and Croker, R.A. (Eds), Qualitative Research in Applied Linguistics A practical Introduction (pp. 182-199). London, UK: Palgrave Macmillan.

Pérez-González, L. (2014). Multimodality in Translation \& interpreting Studies. in Bermann, Sandra and Catherine Porter (2014) (eds) A Companion to Translation Studies (pp. 119-131) Chichester: Wiley-Blackwell, 119131. Available online at: http://eu.wiley.com/WileyCDA/WileyTitle/pro ductCd-0470671890.html

Rennert, S. (2008). "Visual Input in Simultaneous Interpreting”. Meta 53 (1), pp. 204-207.

Septaviana, SR. (2014). Students' Interpreter Performance. Transcon Proceeding, 4 th Atmajaya International Conference on Translation and Interpretation.

Tateyama, Y. (2008). Basic Interpreting Skills. University of Hawaii. http://www.hawaii.edu/eall/nl/200810nl.ht ml. Retrieved on January 2009.

Viaggio, S. (1997). "Kinesics and the simultaneous interpreter. The advantages of listening with one's eyes and speaking with one's body". In Nonverbal Communication and Translation, (pp. 283- 293). F. Poyatos (ed.). Amsterdam and Philadelphia: John Benjamins.

Weale, E. (1997). "From Babel to Brussels. Conference interpreting and the art of the impossible". In Nonverbal Communication and Translation, F. Poyatos (ed.). Amsterdam and Philadelphia: John Benjamins.

Yin, R. K. (2003). Case Study Research. London: Sage Publications.

Zhong, W. (2003). Memory Training in Interpreting. Translation Journal, Retrieved on February, 2008 at http://accurapid.com/journal/25interpret.htm 